\title{
LESSON 75
}

MARGINS: Pica, 20-70; Elite, Type each line 3 times paying attention to good typing technique. $30-80$.

Clinic

Revise $r$ key

Keep the asd fingers in position as you type $r$ with the $f$ finger.

Increase Speed

35 wpm 4 minutes.

S33 - SI 1.05

\section{Improve Accuracy}

30 wpm 4 minutes.

A29 - SI 1.41

Test your Skill

4 minutes.

Use double-line spacing.

Change the margins to:

Pica, 10-72; Elite, 12-88, and make up your own right-hand margin.

T15 - SI 1.42

UNIT 19
1. rat rib rug rot rate rare rest ring rear robe roar

2. for more lard dire dress prove royal arrest arrive

3. Race Robert round your track for your first score.

A piece of wood. What does that bring to the mind? A tree, a log or a work of art? As you sit at your machine you are at work on a piece of wood in a form not quite the way you would see it, were it in its natural state. As you type, you type on a sheet of paper and this is made from wood. Your desk, or part of it, may well be made of wood, and as you look round the room, you are bound to see a great many things that started life, as a piece of wood. To some, a piece of wood is a life spent in work outside in some great forests. A quiet life, and one far from that of the saw mill, where those at work see the wood as work to be cut up. A life of dirt, din and sawdust.

How do you see a piece of wood?

Transport is one of the main aids to Commerce and without it trade would be impossible. The raw materials for so many of the manufactured goods we need in a modern society are found in many varying parts of the world and they must be transported to those parts of the world where they can be changed from raw materials to marketable goods. Nature is kind in so much as there are huge natural deposits of raw materials in various places but Nature does not always put them where they will be used.

Natural products tend to be bulky in relation. to their value and man has devised some cheap ways of transporting them.

Insurance is based on the "pooling of risks." This means that although all could suffer any loss it is agreed to spread the loss sustained by those who are unfortunate enough to incur it, over those who take the precaution of covering themselves and join the pool. The compensation paid out to those who suffer loss is from the premiums paid into the insurance company. The bigger the risk the bigger the contribution to the pool.

It is the job of an actuary to see that there is a big enough pool for all claims to be met over a period of time and still leave some profit. The profit is due to the company for carrying the risk and organizing the insurance.

\begin{tabular}{|c|c|c|c|c|c|c|c|c|c|c|}
1 & 2 & 3 & 4 & 5 & 6 & 7 & 8 & 9 & 10
\end{tabular}

